\title{
Diversity of infectious aetiologies of acute undifferentiated febrile illnesses in south and Southeast Asia: a systematic review
}

Kinley Wangdi ${ }^{i^{* \dagger}} \mathbb{D}$, Kaushalya Kasturiaratchi ${ }^{2 \dagger}$, Susana Vaz Nery ${ }^{1,3}$, Colleen L. Lau ${ }^{1,4}$, Darren J. Gray ${ }^{1 \dagger}$ and Archie C. A. Clements ${ }^{1,5+}$

\begin{abstract}
Background: Acute undifferentiated febrile illness (AUFI) is caused by a multitude of diverse pathogens, with significant morbidity and mortality in the developing world. The objective of this review was to characterise the diversity and relative importance of common infectious aetiologies of AUFI in South and Southeast Asia.

Methods: We conducted a comprehensive literature review to identify common aetiologies of AUFI in Asian countries. Four medical and life sciences databases including PubMed, Medline, Embase and Cochrane Central, and Google Scholar were searched for articles published from January 1998 to March 2019.

Results: Forty-three studies met the inclusion criteria. Among AUFI cases, viral aetiologies at 18.5\% (14888) were more common than bacterial aetiologies (12.9\% [10384]). From 80,554 cases, dengue fever was the most common aetiology $(11.8 \%, 9511)$, followed by leptospirosis $(4.4 \%, 3549)$, typhoid $(4.0 \%, 3258)$, scrub typhus $(4.0 \%, 3243)$ and influenza other than $\operatorname{H1N} 1(3.1 \%, 2514)$. In both adults and children: dengue fever was the leading cause of AUFI with $16.6 \%$ (1928) and 18.7\% (1281) of the total cases. In admitted patients, dengue fever was the main cause of AUFI at 16.4\% (2377), however leptospirosis at 13.9\% (2090) was the main cause of AUFI for outpatients. In South Asia, dengue fever was the main cause of AUFI, causing 12.0\% (6821) of cases, whereas in Southeast Asia, leptospirosis was the main diagnosis, causing $12.1 \%$ (2861) of cases.

Conclusions: In this study the most common causes of AUFI were viral, followed by bacterial and protozoal (malaria) infections. Dengue was the commonest virus that caused AUFI while leptospirosis and typhoid were important bacterial infectious causes. Therefore, it is imperative to maintain a sound epidemiological knowledge of AUFI so that evidence-based diagnostic criteria and treatment guidelines can be developed.
\end{abstract}

Keywords: Acute undifferentiated febrile illness, Asia, Infection

\section{Background}

During the past 20 years, there has been a dramatic emergence and re-emergence of viruses, bacteria and parasitic infections, including novel pathogens as well as those previously believed to be under control. Many of these pathogens cause acute undifferentiated febrile illness (AUFI, or acute febrile illness, AFI). The common

\footnotetext{
*Correspondence: kinley.wangdi@anu.edu.au

${ }^{\dagger}$ Kinley Wangdi and Kaushalya Kasturiaratchi are contributed equally to this article.

${ }^{\dagger}$ Darren J. Gray and Archie C.A. Clements are Joint Senior Authors.

'Department of Global Health, Research School of Population Health,

Australian National University, Action, ACT, Canberra, Australia

Full list of author information is available at the end of the article
}

causes of AUFI include malaria, dengue fever, enteric fever, leptospirosis, rickettsiosis, hantavirus and Japanese encephalitis [1-3]. AUFI contributes to substantial morbidity and death among children and adults worldwide $[4,5]$. Many preventable deaths occur because of incorrect or delayed diagnosis, largely due to limited access to medical care and laboratory diagnostic facilities in the developing countries [6-9]. The majority of patients present with non-specific symptoms such as low-grade fever, general malaise, headache, arthralgia, myalgia, and rash; and usually without a focal point of infection. The symptoms and differential diagnoses of these diseases

(c) The Author(s). 2019 Open Access This article is distributed under the terms of the Creative Commons Attribution 4.0 International License (http://creativecommons.org/licenses/by/4.0/), which permits unrestricted use, distribution, and reproduction in any medium, provided you give appropriate credit to the original author(s) and the source, provide a link to the Creative Commons license, and indicate if changes were made. The Creative Commons Public Domain Dedication waiver (http://creativecommons.org/publicdomain/zero/1.0/) applies to the data made available in this article, unless otherwise stated. 
are similar, making accurate clinical diagnosis difficult without laboratory confirmation [10-12].

In recent decades, dengue has rapidly emerged as a major cause of AUFI in tropical Asia particularly in the World Health Organization (WHO) Southeast Asia (SEA) region [13, 14]. However, many other infectious diseases can cause a dengue-like illness with thrombocytopaenia, including scrub typhus, chikungunya, infectious mononucleosis, malaria, typhoid fever, leptospirosis and acute human immuno-deficiency virus conversion disease [15]. Presumptive diagnosis and reporting of AUFI with thrombocytopaenia as dengue infection would lead to over-reporting of this infection and under-reporting of other illnesses.

Evidence-based decision-making in health requires the availability of sound data, but good quality information on the occurrence of infectious diseases is unavailable for most countries in Asia [16]. The provision of accurate epidemiological data for common pathogens will enable identification of changing patterns of disease aetiology and burden, allowing informed priority setting, and optimal allocation of resources to key areas. Understanding the common causes of AUFI in resource-poor settings in tropical and subtropical countries will help improve case management. In areas where there is limited access to laboratory diagnosis, the local epidemiology of AUFI and validated clinical predictors may help guide presumptive diagnosis and therapeutic interventions. Such information is also crucial for developing appropriate diagnostic tests and guidelines, and informing resource mobilization and public health interventions. Therefore, the objective of this review was to synthesise information on the diversity and relative importance of common infectious aetiologies of AUFI in recent history in South and Southeast Asia given it is a melting point of tropical infectious diseases and a hotspot for disease emergence $[14,17,18]$.

\section{Methods}

\section{Search strategy and inclusion criteria}

A systematic literature review was undertaken in four medical and life sciences databases including PubMed, Medline, Embase and Cochrane Central, and Google Scholar search machine was also used. Publications from the last 21 years (January 1998-March 2019) were included because laboratory tests and diseases patterns have changed during recent decades in many parts of South and Southeast Asia. Articles were obtained electronically or in paper form. The search words included: i) aetiology OR etiology OR causes AND ii) acute febrile illnesses OR iii) undifferentiated fevers AND Asia OR Thailand OR Malaysia OR Singapore OR India OR Sri Lanka OR Nepal OR Bangladesh OR Pakistan OR Vietnam OR Laos OR Cambodia OR Indonesia OR
Myanmar OR Timor-Leste OR Bhutan OR Maldives OR Philippines. The review included articles published in English only.

We did not limit our search by study design or patient age. Data were derived from studies on inpatients as well as outpatients with AUFI with no focus of infections identified after taking a detailed history and clinical examination. Inclusion criteria were: a) primary articles, published in peer review journals on AFI/AUFI in South Asia (Bhutan, Bangladesh, India, Nepal, and Sri Lanka) and Southeast Asia (Cambodia, Laos, Indonesia, Malaysia, Myanmar, Philippines, Singapore, Thailand, and Vietnam); b) published reports between January 1998 and March 2019 (to improve the reliability of laboratory confirmation and to reflect the distribution of more recent disease patterns) and c) published in English. Exclusion criteria included: a) studies carried out in other parts of Asia (Middle East and central Asia); b) studies conducted before 1998; c) articles such as preliminary reports, and case reports; d) editorials, opinions, review articles, vaccine and drug trials; and e) case reports and fever associated with a travel history (Additional file 1: Table S1). Titles and abstracts were screened for compliance with the inclusion criteria and then full papers were reviewed.

\section{Data analysis}

The selection of citations by title and abstract was carried out independently by two researchers (KW and SKK). The selected studies underwent a full-text review for all potentially relevant studies. Data from the 43 included studies were independently extracted in a spreadsheet by KW and SKK. Information from each paper was extracted and entered in to a Microsoft Excel (2010 version) spread sheet. Descriptive data included study location, study period, type of patients (inpatients/ outpatients/ both), age range and duration of fever. Quantitative data recorded included number of patients, pathogens isolated, and common presenting signs and symptoms. Paediatric data were defined as those that included patients younger than 16 years. Studies with nonsegregated data for adults and children were analysed separately. Data for pathogens isolated in each study were compiled and analysed in aggregate to compare common aetiologies of AUFI. The proportion of fevers confirmed through laboratory diagnosis in each study were recorded as the main outcome measure.

\section{Risk of bias assessment}

The risk of bias (ROB) of the included studies was assessed using a modified checklist used previously [19]. The studies were assessed using eight questions with a possible maximum count of eight safe-guards (Additional file 1: Table S2), with three questions to 
assess external validity, and five questions for internal validity. We did not assess the ROB for the sampling methodology of populations with acute febrile illness, as these were defined populations presenting to a health facility with acute infection and no population-based sampling was used to capture these populations.

\section{Results}

\section{Identification of studies}

Using the key words in the search, 2064 articles were identified from four life science data base (PubMed, Medline, Web of Science, Embase) and Google Scholar. The titles and abstracts of all studies identified by the search strategy were screened for their relevance to this review and 1640 records that were not relevant for fever with infectious aetiologies were discarded. Four hundred fifteen (424) reports were screened further and from those records, 366 were excluded after reviewing the abstracts as they did not meet the inclusion criteria. All remaining 58 full text articles were reviewed using pre-determined criteria. A full-text review led to the exclusion of a further 15 papers, including five studies with potentially relevant data that were excluded as three of them were carried out in 1991, one study in 1994 and the other study from 1994 to 1999 . The remaining 43 studies were from 11 countries in South and Southeast Asia, including a multicentre study, were then analysed (Fig. 1).

\section{Characteristics of included studies}

Twenty-eight studies were from South Asia, of which 20 were from India. In the South East Asia, there were 15 studies and Thailand reported the highest number of studies in the region with nine studies (Fig. 2). There was one multi-centre study carried out in Indonesia, Malaysia, Philippines, Thailand and Vietnam. Most were prospective studies $(n=31)$ and six studies were retrospective; three were cross-sectional; one cohort study and two active fever surveillance (Table 1).

Definition of fever duration in the acute febrile illnesses described in these studies varied widely, from 1 to 30 days. Of the 43 included studies, 19 included duration of fever of $<14$ days [2, 11, 20-36], seven studies had fever duration of $<21$ days $[7,12,37-41]$, three studies reported fever with the duration of $<30$ days [1, 42, 43], 13 studies did not define any specific duration [44-56] and one study recruited patients with acute fever of more than 4 days [57]. Similarly, the temperature threshold used to define fever varied from $37.5-38.5^{\circ}$ Celsius. Sixteen studies included adult (> 16 years) patients $[1,12,21,22,32,36-38,40,45$, $47,49-52,55]$, eight studies included children $(<16$ years) $[7,11,25,27,39,41,42,54]$ and 19 studies included patients of all ages [2, 20, 23, 24, 26, 28-31, $33-35,43,44,46,48,53,56,57]$. The number of patients involved in each study varied from 50 to 38 , 635. Data on a total of 80,554 patients were included

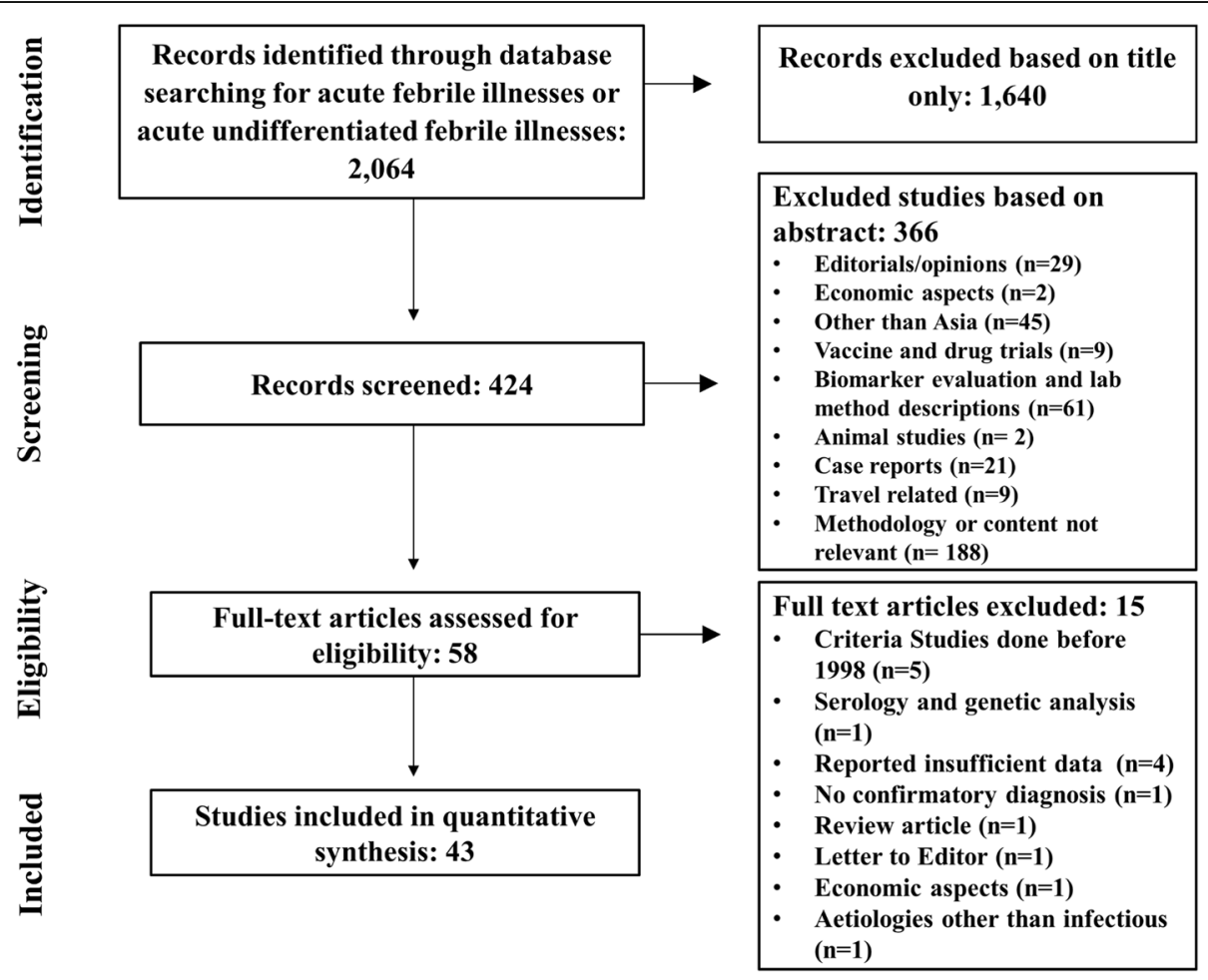

Fig. 1 Study selection 


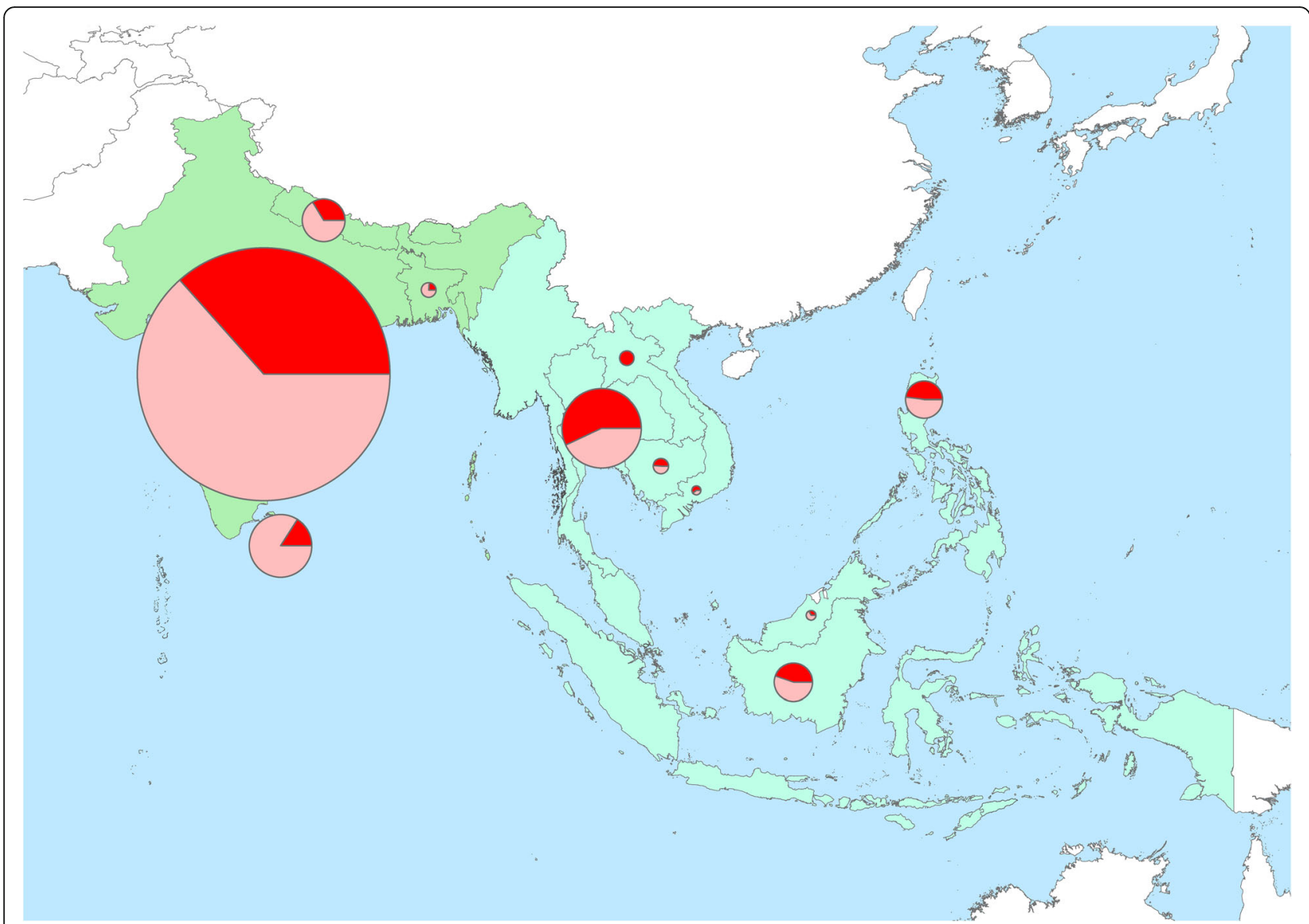

Fig. 2 Summary of the studies by countries and regions. The size of the circles indicates the relative number of patients and light colour is the proportion of study subjects with unidentified aetiology. Countries with blue colour are in South East Asia and green colour are in South Asia

in the analysis of which $14.4 \%$ (11706) were adults, $8.5 \%$ (7840) were children and $77.1 \%$ (62068) were not specified either as adults or children and 39 cases could not be assigned to any age groups [35]. Among adults, mean age varied from 27 to 39.5 years and among children from 2 to 9.5 years. There were 19 , 030 males, 14,625 females (with a male to female ratio of 1.3:1), and gender was not reported for 46,899 patients.

Twenty-five studies included patients admitted to hospital [1, 7, 12, 21-23, 27, 32-35, 37, 38, 40-45, $47,48,50,52,55,57]$ making up $18.7 \%$ (14420) of the total study sample (80554). Six studies included patients attending outpatients department corresponding to $18.7 \%$ (15075) of study sample $[2,11,20,24$, 28, 39]. Twelve studies included patients attending outpatient departments (OPD) and those admitted to hospital wards representing 63.4\% (51059) of total study sample [25, 26, 29-31, 36, 46, 49, 51, 53, 54, 56]. Common presenting symptoms were given in 24 studies, corresponding to 30,397 patients. Amongst these 23 studies, the most common presenting symptom was headache
$39.7 \%$ (12072) followed by cough $29.7 \%$ (9035) and chills 20.5\% (6241) (Additional file 1: Table S3).

In all studies excepting one [34], diagnoses were made according to interpretation of antibody titres. Pathogenspecific IgM titres were determined by using IgMcapture enzyme-linked immunosorbent assay (ELISA) kits, which are commercially available. Molecular testing (using polymerase chain reaction [PCR] was carried out in 16 studies [24-27, 29, 30, 35, 38-40, 42, 49, 50, 5456]. Serological diagnoses were confirmed by blood cultures in 16 studies out of 43 [2, 20-22, 24, 26, 32, 37, 40, $42,43,45,47,48,50,51]$. Microscopy was used for the diagnosis in 15 studies [20-22, 24, 26, 32, 37, 43, 44, 46, $47,49-51,55]$. Nucleotide sequencing was done in two studies [29, 35] (Fig. 3 and Additional file 1: Table S4).

Aetiology of AUFI was identified in $37.7 \%$ (30333) of patients: with viral aetiologies in $18.5 \%$ (14888) being the most common, followed by bacterial and protozoal aetiologies with $12.9 \%$ (10384), and $2.8 \%$ (2281) respectively. The underlying diagnosis could not be ascertained in $64.6 \%$ of patients (52003). Twenty studies reported 378 deaths in patients with AUFI $[1,2,20-22,25-27$, 


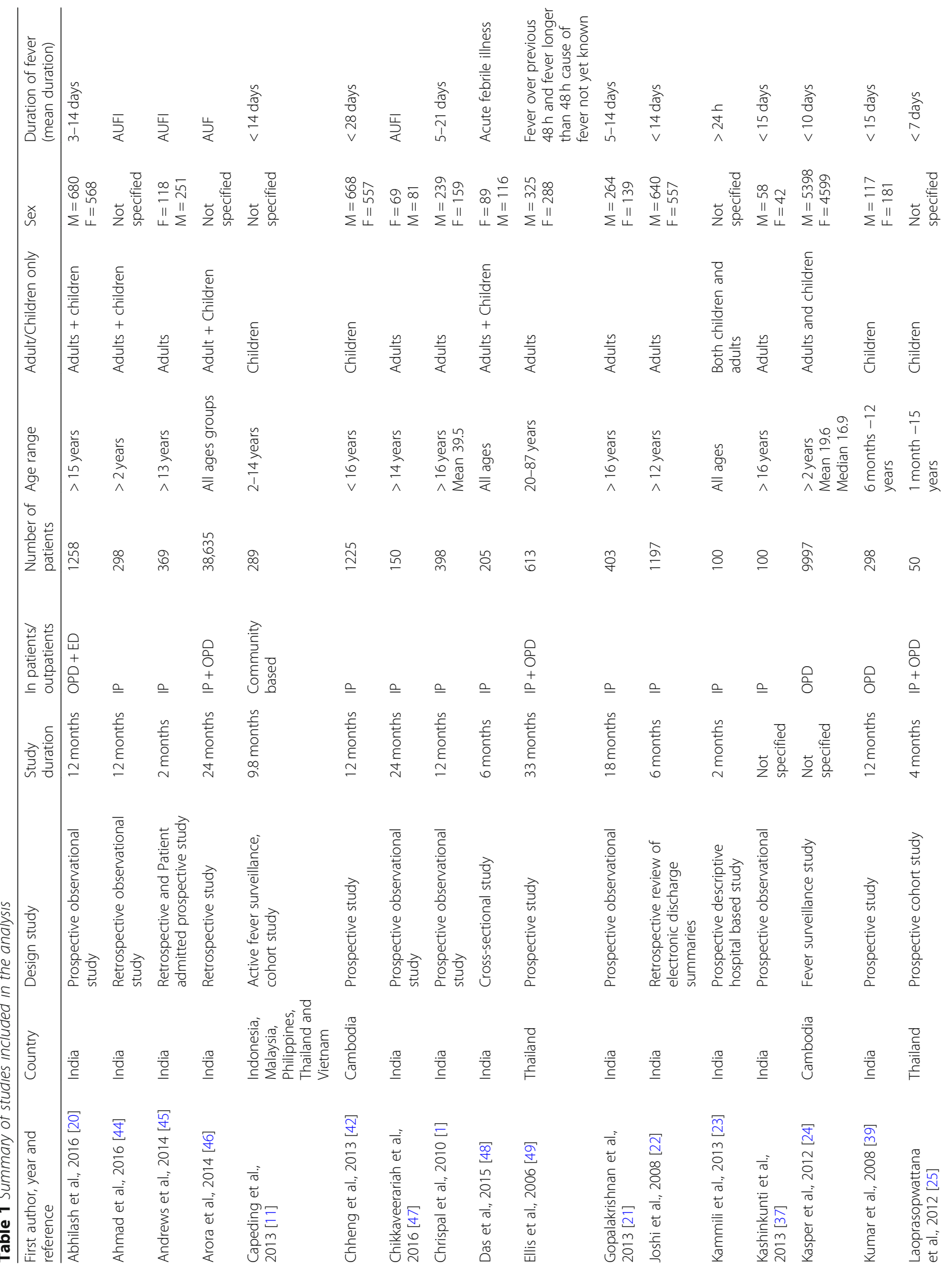




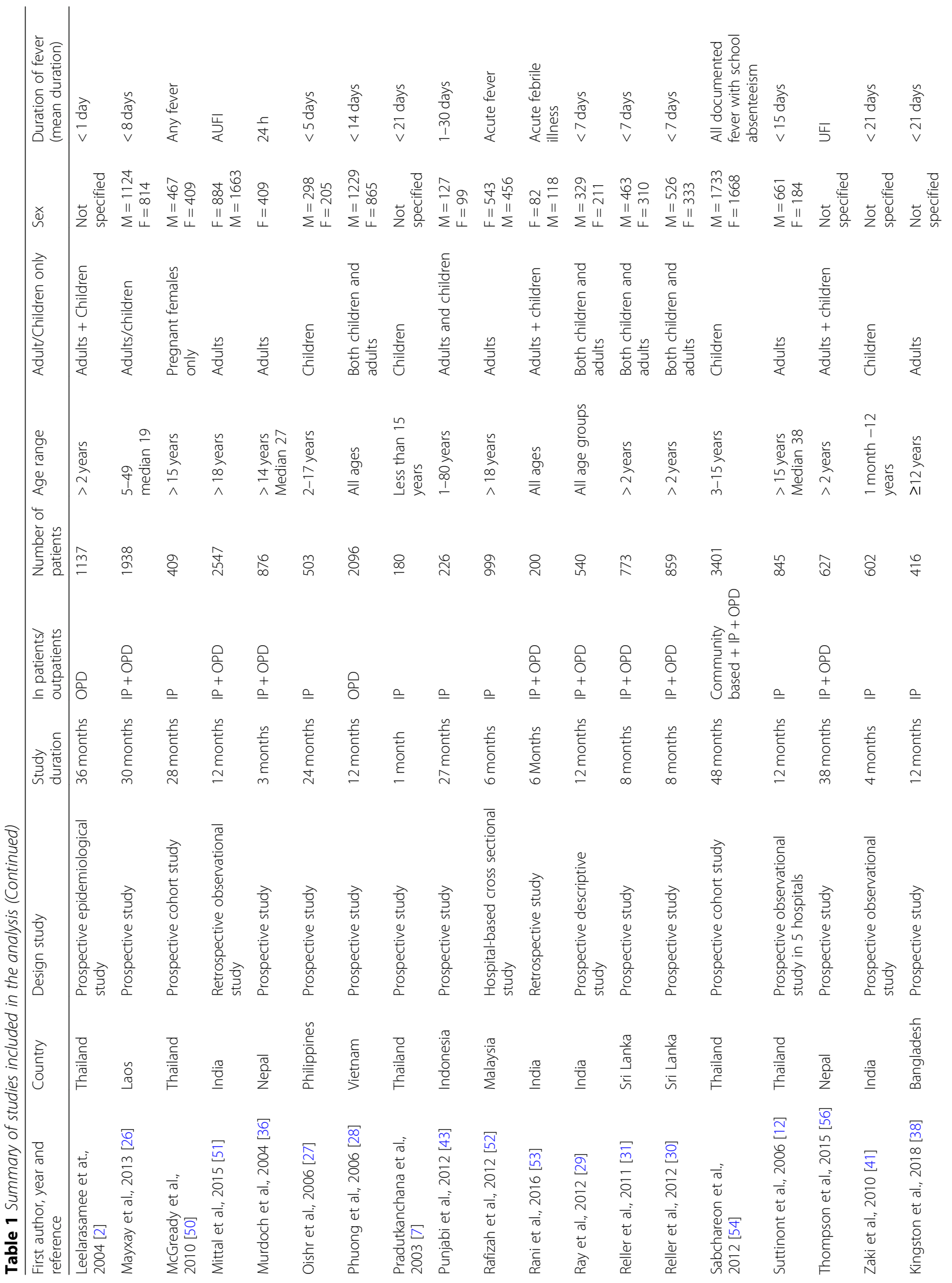




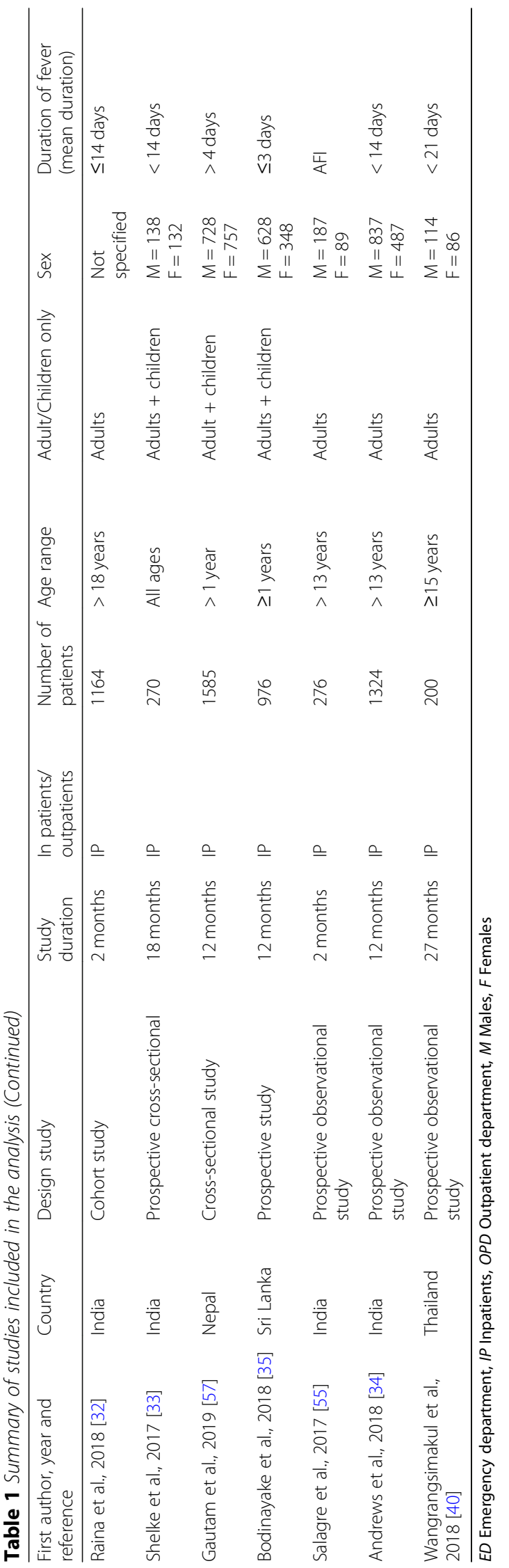


$31,34,36,38,41-45,48-50]$. Co-infections were reported in $1.2 \%$ (981) of total cases, the most common co-infections with two organisms $0.9 \%$ (740).

\section{Aetiology of AUFI by age group}

In adults, the commonest infection was from bacterial causes at $26.1 \%$ (3037), followed by viral aetiologies $18.6 \%$ (2169). The most common aetiologies of AUFI in adults were dengue fever $16.6 \%$ (1928), scrub typhus $10.7 \%$ (1244), malaria 9.8\% (1139), leptospirosis $6.3 \%$ (732) and typhoid $6.0 \%$ (696). On the other hand, viral infection was the commonest cause of fever among children corresponding to $23.8 \%$ (1625) of the diagnosed cases, followed by bacterial aetiologies and malaria (corresponding to 6.4\% (435) and $0.8 \%$ (57) of diagnosed cases, respectively). Dengue fever, chikungunya, and typhoid were the commonest cause of AUFI in children representing 18.7\% (1281), $1.7 \%(114)$, and $1.6 \%$ (107) respectively. In the unspecified age group (UAG), dengue fever was the commonest cause of AUFI with 10.2\% (6302) of total cases; leptospirosis was the second commonest cause with 4.4\% (2729); typhoid and malaria contributed $4.0 \%(2455)$ and $1.7 \%(1085)$ of total cases (Table 2 and Fig. 4).

\section{Aetiology of AUFI by site of patient recruitment}

Among the 14,450 hospitalised patients, bacterial infection $23.1 \%$ (3340) was the leading cause of fever.
However, the most common aetiology of AUFI was dengue fever $16.4 \%$ (2377), followed by scrub typhus $10.0 \%$ (1449), malaria 6.9\% (990), and leptospirosis $6.8 \%$ (989). A total of 7053 representing $48.8 \%$ did not have a known diagnosis. Even though viral infections $(36.7 \%, 5536)$ were the main cause for fever in outpatients, leptospirosis $13.9 \%$ (2090) was the commonest cause of AUFI followed by influenza other than HINI 13.8\% (2077), dengue 8.5\% (1277), and hepatitis E $6.9 \%$ (1038). Dengue was the commonest infection in patients recruited from both IP and OPD $11.5 \%$ (5857), followed by typhoid 3.8\% (1940), malaria $2.4 \%(1234)$, scrub typhus $2.3 \%$ (1165), and leptospirosis $0.9 \%$ (470) respectively (Table 3 and Fig. 4).

\section{Aetiology of AUFI by region}

In both the regions, viral aetiologies were the leading cause of AUFI with 33.0\% (7828) and 12.4\% (7060) for SEA and South Asia, respectively. However, there was significant differences in the burden of AUFI when stratified by individual aetiologies. In South Asia, the commonest cause of fever was dengue fever $12.0 \%$ (6821) followed by typhoid $4.3 \%$ (2449), and malaria $3.0 \%$ (1722). While Leptospirosis was the leading infection $12.1 \%$ (2861) in SEA followed by dengue fever $11.4 \%$ (2690), influenza other than H1N1 10.6\% (2511), and hepatitis E $4.4 \%$ (1038) (Table 4 and Fig. 4).

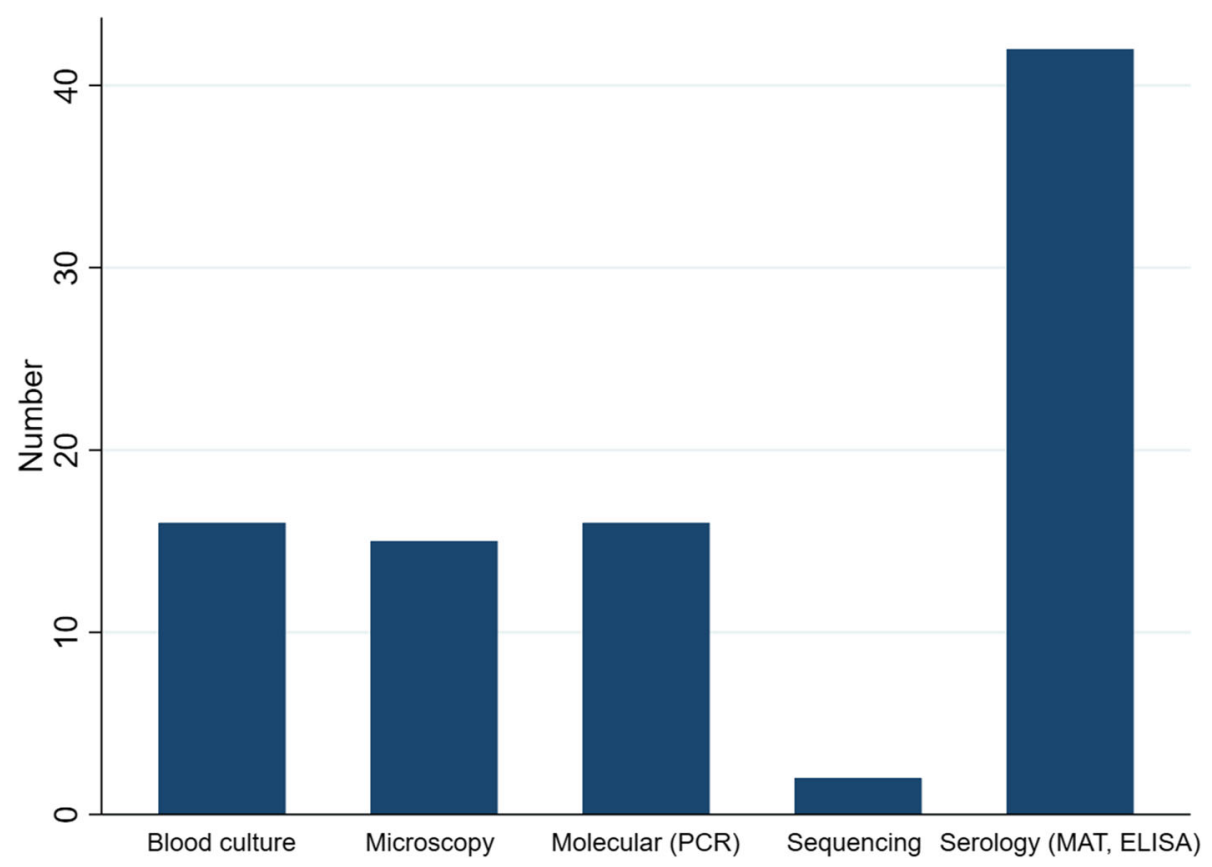

Fig. 3 Summary of different diagnostic methods. (MAT- microscopic agglutination test; ELISA- enzyme-linked immunosorbent assay; PCRpolymerase chain reaction) 
Table 2 Common aetiologies of AUFI stratified by age

\begin{tabular}{|c|c|c|c|c|}
\hline Organism & Adults $(n ; \%)$ & Children $(n ; \%)$ & UAG $(n ; \%)$ & Total $\quad(n ; \%)$ \\
\hline Viral aetiologies & $2169(18.6)$ & $1625(23.8)$ & $11,094(17.9)$ & $14,888(18.5)$ \\
\hline Dengue & $1928(16.6)$ & $1281(18.7)$ & $6302(10.2)$ & $9511(11.8)$ \\
\hline$J E^{* * *}$ & $5(0.0)$ & $71(1.0)$ & $233(0.4)$ & $309(0.4)$ \\
\hline Influenza ${ }^{* *}$ & $180(1.5)$ & $48(0.7)$ & 2286 (3.7) & $2514(3.1)$ \\
\hline H1N1 & $5(0.0)$ & $1(0.0)$ & $513(0.8)$ & $519(0.6)$ \\
\hline Chikungunya & $15(0.1)$ & $114(1.7)$ & $326(0.5)$ & $455(0.6)$ \\
\hline Hepatitis A & $8(0.1)$ & $7(0.1)$ & $58(0.1)$ & $73(0.1)$ \\
\hline Hepatitis B & $5(0.0)$ & $0(0.0)$ & $267(0.4)$ & $272(0.3)$ \\
\hline Hepatitis E & $2(0.0)$ & $0(0.0)$ & $1038(1.7)$ & $1040(1.3)$ \\
\hline Flavi virus & $0(0.0)$ & $65(1.0)$ & $0(0.0)$ & $65(0.1)$ \\
\hline Para influenza 1 & $0(0.0)$ & $10(0.1)$ & $0(0.0)$ & $10(0.0)$ \\
\hline Para influenza 3 & $0(0.0)$ & $28(0.4)$ & $0(0.0)$ & $28(0.0)$ \\
\hline Hanta virus & $2(0.0)$ & $0(0.0)$ & $71(0.1)$ & $73(0.1)$ \\
\hline HIV & $19(0.2)$ & $0(0.0)$ & $0(0.0)$ & $19(0.0)$ \\
\hline Bacterial aetiologies & $3037(26.1)$ & $435(6.4)$ & $6912(11.1)$ & $10,384(12.9)$ \\
\hline Leptospirosis & $732(6.3)$ & $88(1.3)$ & $2729(4.4)$ & $3549(4.4)$ \\
\hline Typhoid & $696(6.0)$ & 107 (1.6) & $2455(4.0)$ & $3258(4.0)$ \\
\hline Paratyphoid & $57(0.5)$ & $0(0.0)$ & $0(0.0)$ & $57(0.1)$ \\
\hline Rickettsiosis diseases & 1449 (12.5) & $140(2.0)$ & $1654(2.7)$ & $3243(4.0)$ \\
\hline Scrub typhus & $1244(10.7)$ & $103(1.5)$ & $1512(2.4)$ & $2859(3.5)$ \\
\hline Murine typhus & $171(1.5)$ & $0(0.0)$ & $101(0.2)$ & $272(0.3)$ \\
\hline Spotted fever & $34(0.3)$ & $37(0.5)$ & $41(0.1)$ & $112(0.1)$ \\
\hline Q fever & $7(0.1)$ & $0(0.0)$ & $0(0.0)$ & $7(0.0)$ \\
\hline E coli & $11(0.1)$ & $21(0.3)$ & $26(0.0)$ & $58(0.1)$ \\
\hline Burkholderia pseudomallei & $3(0.0)$ & $14(0.2)$ & $6(0.0)$ & $23(0.0)$ \\
\hline Tuberculosis & $29(0.2)$ & $6(0.1)$ & $8(0.0)$ & $43(0.1)$ \\
\hline Klebsiella pneumoniae & $1(0.0)$ & $0(0.0)$ & $2(0.0)$ & $3(0.0)$ \\
\hline Haemophilus influenza & $0(0.0)$ & $0(0.0)$ & $9(0.0)$ & $9(0.0)$ \\
\hline Staph aureus & $0(0.0)$ & $37(0.5)$ & $12(0.0)$ & $49(0.1)$ \\
\hline Strep pneumoniae & $51(0.4)$ & $18(0.3)$ & $6(0.0)$ & $75(0.1)$ \\
\hline Strep Gr A & $0(0.0)$ & $0(0.0)$ & $2(0.0)$ & $2(0.0)$ \\
\hline Strep Gr C & $0(0.0)$ & $0(0.0)$ & $1(0.0)$ & $1(0.0)$ \\
\hline Neisseria meningitis & $1(0.0)$ & $4(0.1)$ & $2(0.0)$ & $7(0.0)$ \\
\hline Protozoa & $1139(9.8)$ & $57(0.8)$ & $1085(1.7)$ & $2281(2.8)$ \\
\hline Malaria & $1139(9.8)$ & $57(0.8)$ & $1085(1.7)$ & $2281(2.8)$ \\
\hline Fungal aetiologies & $0(0.0)$ & $0(0.0)$ & $3(0.0)$ & $3(0.0)$ \\
\hline Yeast non-Cryptococci & $0(0.0)$ & $0(0.0)$ & $2(0.0)$ & $2(0.0)$ \\
\hline Cryptococcus neoformans & $0(0.0)$ & $0(0.0)$ & $1(0.0)$ & $1(0.0)$ \\
\hline Co infections & $251(2.2)$ & $30(0.4)$ & $700(1.1)$ & $981(1.2)$ \\
\hline Co infection ${ }^{*}$ & $226(1.9)$ & $30(0.4)$ & $484(0.8)$ & $740(0.9)$ \\
\hline Co infection ${ }^{\dagger}$ & $25(0.2)$ & $0(0.0)$ & $210(0.3)$ & $235(0.3)$ \\
\hline
\end{tabular}


Table $\mathbf{2}$ Common aetiologies of AUFI stratified by age (Continued)

\begin{tabular}{|c|c|c|c|c|}
\hline Organism & Adults $(n ; \%)$ & Children ( $n$; \%) & UAG $(n ; \%)$ & Total $\quad(n ; \%)$ \\
\hline Co infection ${ }^{\ddagger}$ & $0(0.0)$ & $0(0.0)$ & $6(0.0)$ & $6(0.0)$ \\
\hline Unknown/others & $5036(43.3)$ & $4693(68.6)$ & $42,274(68.1)$ & $52,003(64.6)$ \\
\hline Deaths & $125(33.1)$ & $81(21.4)$ & $172(45.5)$ & $378(100.0)$ \\
\hline
\end{tabular}

\section{Case fatalities}

A total of 378 deaths were reported across 20 studies corresponding to a case fatality rate (CFR) of $0.5 \%$. There were 114 deaths in the SEA region with a CFR of $0.5 \%$. In South Asia, the CFR was $0.5 \%$ with 264 deaths. More than half (172) of the deaths were in patents whose age was unknown, with a case fatality of $0.3 \%$, followed by children with 81 deaths (CFR of $1.2 \%$ ), and adults with 112 deaths (CFR 1.3\%). Most of the deaths occurred in hospitalised patients 270 (CFR 1.9\%) followed by both inpatients and outpatients 78 (CFR 0.2\%).

\section{Risk of bias}

The quality of the studies including types of study, randomization and other characteristics was assessed through eight safeguards against bias as outlined in the Additional file 1: Table S2. The ranges of score were 4-8. The most common safeguard missing was study's target population. Only 15 studies recruited patients of all ages presenting with AUFI. The other studies restricted study population either to children or adults. All studies had study instrument that had validity and reliability (Additional file 1: Table S5).

\section{Discussion}

The findings of this review illustrate that in tropical and subtropical South and Southeast Asian countries, the most common causes of AUFI were viruses, followed by bacteria and malaria. Generally, dengue fever was the commonest cause followed by leptospirosis and typhoid. Consistent with our findings, the decline in malaria cases in Asia and Africa has resulted in a relative increase in non-malarial AUFIs in these continents [58]. Non-malarial fever was responsible for $20-50 \%$ of all fevers in Asia and Africa in children over 5 years of age and adults [59]. While dengue was mostly frequently reported febrile illness in Latin America [60].

Leptospirosis was the leading cause of AUFI in the Southeast region similar to other reported studies from that region [61-65], in agricultural workers [66, 67] and mostly in males [68]. The ability of all countries in the

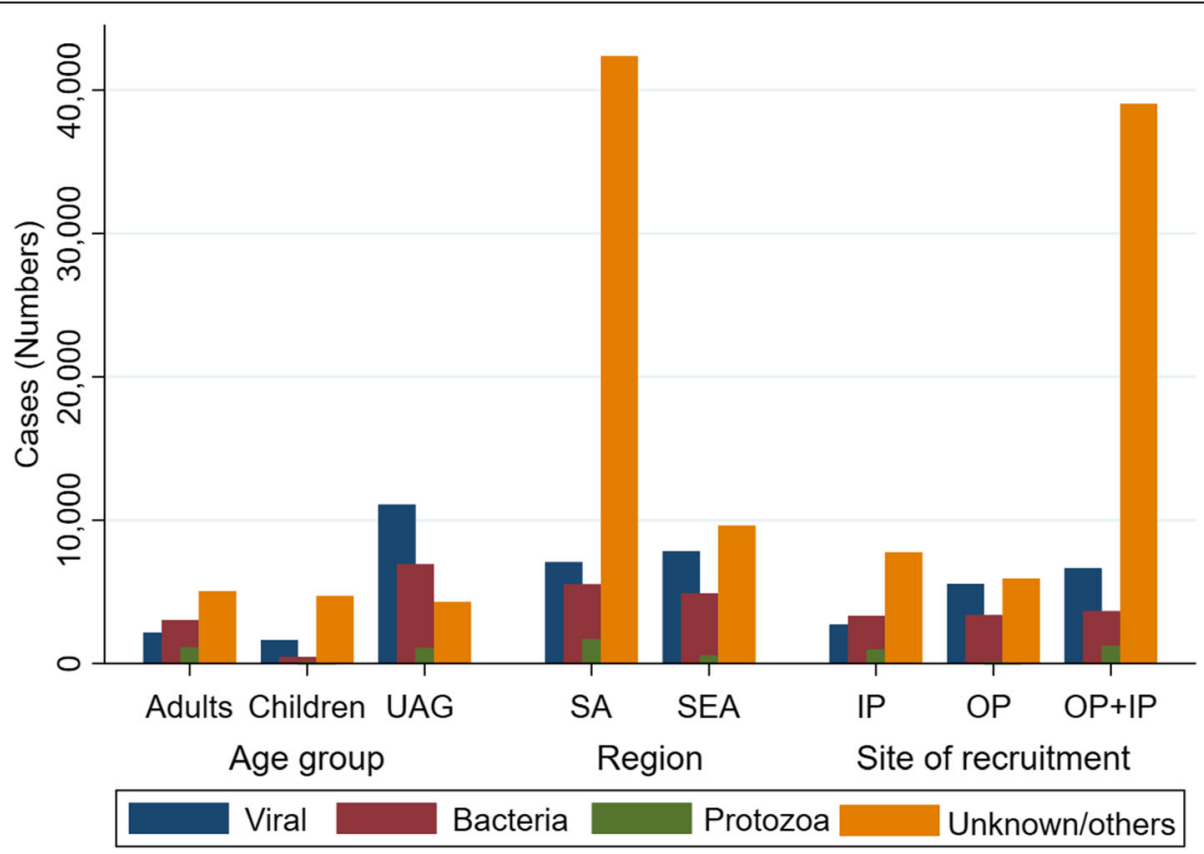

Fig. 4 Summary graph of main categories of AUFI across age group, region and site of patient recruitment in Asia. (UAG- unknown age group, IP-inpatient; OP-outpatient; SEA-Southeast Asia, SA- South Asia) 
Table 3 Aetiology of AUFI by site of patient recruitment

\begin{tabular}{|c|c|c|c|c|}
\hline Organism & $\mathrm{IP}(n ; \%)$ & $\mathrm{OP}(n ; \%)$ & $\mathrm{OP}+\mathrm{IP}(n ; \%)$ & Total (n; \%) \\
\hline Viral aetiologies & $2721(18.8)$ & $5536(36.7)$ & $6631(13.0)$ & $14,888(18.5)$ \\
\hline Dengue & $2377(16.4)$ & $1277(8.5)$ & $5857(11.5)$ & $9511(11.8)$ \\
\hline$J E^{* * *}$ & $77(0.5)$ & $7(0.0)$ & $225(0.4)$ & $309(0.4)$ \\
\hline Influenza ${ }^{* *}$ & $86(0.6)$ & 2077 (13.8) & $351(0.7)$ & $2514(3.1)$ \\
\hline $\mathrm{HINI}$ & $6(0.0)$ & $513(3.4)$ & $0(0.0)$ & $519(0.6)$ \\
\hline Chikungunya & $54(0.4)$ & $224(1.5)$ & $177(0.3)$ & $455(0.6)$ \\
\hline Hepatitis A & $0(0.0)$ & $62(0.4)$ & $11(0.0)$ & $73(0.1)$ \\
\hline Hepatitis B & $4(0.0)$ & $267(1.8)$ & $1(0.0)$ & $272(0.3)$ \\
\hline Hepatitis E & $2(0.0)$ & $1038(6.9)$ & $0(0.0)$ & $1040(1.3)$ \\
\hline Flavi virus & $65(0.4)$ & $0(0.0)$ & $0(0.0)$ & $65(0.1)$ \\
\hline Para influenza 1 & $10(0.1)$ & $0(0.0)$ & $0(0.0)$ & $10(0.0)$ \\
\hline Para influenza 3 & $28(0.2)$ & $0(0.0)$ & $0(0.0)$ & $28(0.0)$ \\
\hline Hanta virus & $1(0.0)$ & $71(0.5)$ & $1(0.0)$ & $73(0.1)$ \\
\hline HIV & $11(0.1)$ & $0(0.0)$ & $8(0.0)$ & $19(0.0)$ \\
\hline Bacterial aetiologies & $3340(23.1)$ & $3383(22.4)$ & $3662(7.2)$ & 10,385 (12.9) \\
\hline Leptospirosis & $989(6.8)$ & $2090(13.9)$ & $470(0.9)$ & $3549(4.4)$ \\
\hline Typhoid & $406(2.8)$ & $912(6.0)$ & 1940 (3.8) & $3258(4.0)$ \\
\hline Paratyphoid & $57(0.4)$ & $0(0.0)$ & $0(0.0)$ & $57(0.1)$ \\
\hline Rickettsial diseases & 1670 (11.6) & $341(2.3)$ & $1232(2.4)$ & $3243(4.0)$ \\
\hline Scrub typhus & $1449(10.0)$ & $245(1.6)$ & $1165(2.3)$ & 2859 (3.5) \\
\hline Murine typhus & $178(1.2)$ & $65(0.4)$ & $29(0.1)$ & $272(0.3)$ \\
\hline Spotted fever & $43(0.3)$ & $31(0.2)$ & $38(0.1)$ & $112(0.1)$ \\
\hline Q fever & $7(0.0)$ & $0(0.0)$ & $0(0.0)$ & $7(0.0)$ \\
\hline E coli & $29(0.2)$ & $25(0.2)$ & $4(0.0)$ & $58(0.1)$ \\
\hline Burkholderia pseudomallei & $17(0.1)$ & $3(0.0)$ & $3(0.0)$ & $23(0.0)$ \\
\hline Tuberculosis & $36(0.2)$ & $0(0.0)$ & $7(0.0)$ & $43(0.1)$ \\
\hline Klebsiella pneumonia & $2(0.0)$ & $0(0.0)$ & $2(0.0)$ & $4(0.0)$ \\
\hline Haemophilus influenza & $9(0.1)$ & $0(0.0)$ & $0(0.0)$ & $9(0.0)$ \\
\hline Staph aureus & $39(0.3)$ & $8(0.1)$ & $2(0.0)$ & $49(0.1)$ \\
\hline Strep pneumonia & $73(0.5)$ & $2(0.0)$ & $0(0.0)$ & $75(0.1)$ \\
\hline Strep Gr A & $1(0.0)$ & $0(0.0)$ & $1(0.0)$ & $2(0.0)$ \\
\hline Strep Gr C & $0(0.0)$ & $0(0.0)$ & $1(0.0)$ & $1(0.0)$ \\
\hline Neisseria meningitis & $5(0.0)$ & $2(0.0)$ & $0(0.0)$ & $7(0.0)$ \\
\hline Protozoa & $990(6.9)$ & $57(0.4)$ & $1234(2.4)$ & $2281(2.8)$ \\
\hline Malaria & $990(6.9)$ & $57(0.4)$ & $1234(2.4)$ & $2281(2.8)$ \\
\hline Fungal aetiologies & $3(0.0)$ & $0(0.0)$ & $0(0.0)$ & $3(0.0)$ \\
\hline Yeast non-Cryptococci & $2(0.0)$ & $0(0.0)$ & $0(0.0)$ & $2(0.0)$ \\
\hline Cryptococcus neoformans & $1(0.0)$ & $0(0.0)$ & $0(0.0)$ & $1(0.0)$ \\
\hline Co infections & $343(2.4)$ & $176(1.2)$ & $496(1.0)$ & $1015(1.3)$ \\
\hline Co infection ${ }^{*}$ & $331(2.3)$ & $169(1.1)$ & $270(0.5)$ & $770(1.0)$ \\
\hline Co infection ${ }^{\dagger}$ & $12(0.1)$ & $7(0.0)$ & $220(0.4)$ & $239(0.3)$ \\
\hline
\end{tabular}


Table 3 Aetiology of AUFI by site of patient recruitment (Continued)

\begin{tabular}{|c|c|c|c|c|}
\hline Organism & IP $(n ; \%)$ & $\mathrm{OP}(n ; \%)$ & $\mathrm{OP}+\mathrm{IP}(n ; \%)$ & Total (n; \%) \\
\hline Co infection $^{\ddagger}$ & $0(0.0)$ & $0(0.0)$ & $6(0.0)$ & $6(0.0)$ \\
\hline Unknown & 7053 (48.8) & $5923(39.3)$ & $39,036(76.5)$ & $52,012(64.5)$ \\
\hline Deaths & 270 (71.4) & $30(7.9)$ & $78(20.6)$ & $378(100.0)$ \\
\hline
\end{tabular}

IP Inpatients, OP Outpatients; ${ }^{* * *}$ JE- Japanese B Encephalitis, HAV Hepatitis A virus; HBV Hepatitis E virus, HEV Hepatitis E virus,

${ }^{* *}$ Influenza other than $\mathrm{H} 1 \mathrm{~N} 1$; ${ }^{*}$ co-infection with two organisms; ${ }^{\dagger}$ co-infection with three organisms; ${ }^{\ddagger}$ co-infection with more than three organisms

The bold face shows the cumulative number of the stratified groups

region to accurately report and monitor leptospirosis hinges strongly on their respective capacity to provide accurate and reliable laboratory diagnosis, and robust reporting and surveillance systems $[69,70]$. While the microscopic agglutination test (MAT) is considered to be the gold standard serological test [71], there are limitations to the test including a need for live cultures of Leptospira of different serogroups, crossreactions between serogroups and serovars, poor sensitivity in the first week of illness, and persistence of high titres for many years after an infection. Conversely, treatment with antibiotics can blunt the immune response in leptospirosis, reducing the number of cases detectable by serology [72]. Hence, the number of leptospirosis patients reported in this review could be under or overestimated.

Dengue was the commonest cause of AUFI in South Asia contrary to Southeast Asia. It is generally a childhood disease and our results are consistent with that trend because it was the commonest cause of AUFI among children [73-75]. In the past, dengue cases were mostly hospitalized irrespective of the severity of the disease. However, with the new admission criteria which includes clinical, laboratory, and dengue haemorrhage fever (DHF) predictive parameters [76], only severe cases of dengue: DHF and dengue shock syndrome (DSS) are admitted. The admission criteria were not clear in our study since most of the cases were from both OPD and IPD.

This review confirms that influenza is also an important cause of AUFI in the region, being the fourth commonest cause. Persistence of influenza virus especially in Southeast Asia is thought to be mediated by domestic ducks and large live poultry markets acting as a virus reservoir [77, 78]. Seasonal influenza is a highly transmissible, abrupt, and usually a self-limiting febrile infection of the respiratory tract and the majority of patients would present to outpatient departments [79, 80]. In many countries, the disease burden from influenza is underestimated because many cases are undiagnosed.

Typhoid fever was also identified as one of the major causes of AUFI. Previous reports have indicated that children are most at risk of developing typhoid fever [81]. The disease remains an important public health problem in developing countries. Similarly, rickettsial diseases including scrub typhus (Orientia tsutsugamushi) and murine typhus (Rickettsia typhi) were responsible for a small fraction of AUFI in this review. However, it is important to note that rickettsial diseases are an important cause of febrile illness worldwide but are often undiagnosed, sometimes leading to life-threatening conditions [82-85]. Given rickettsial infections are treatable causes of AUFI, greater recognition of scrub typhus and murine typhus is important to increase the index of suspicion amongst the physicians so that cases are not missed.

Protozoal infection particularly malaria was responsible for $3.7 \%$ of all AUFI cases. This figure is likely to have been an underestimate because four studies excluded malaria patients in their analysis as their inclusion criteria were non-malarial patients. Of the 11 member countries in the WHO SEA Region, 10 are endemic for malaria. Six countries (Bhutan, Democratic People's Republic of Korea, Indonesia, Nepal, Sri Lanka, and Thailand) are aiming for malaria elimination as a longer-term goal [86], and Sri Lanka has already eliminated malaria [87].

We found that $1.0 \%$ of AUFIs were associated with coinfections, the majority being in inpatients. Patients not responding to treatment for a particular infection or those in whom the presentation was atypical or severe should be suspected of harbouring a second infectious agent. The possibility of co-infections of leptospirosis with hepatitis E virus (HEV) [88] has been described as water is the vehicle of transmission for both pathogens. The under-diagnosis of mixed infections is very likely due to the overlapping clinical spectrum [89]. The relatively high morbidity and mortality in mixed infections underscores the need for greater awareness of the possibility of mixed infections as well as the need for optimal use of microbiological laboratory services to reach a specific diagnosis [88].

Causes of fever remained unknown in more than half of patients with AUFI in this review. Similar findings have been reported in other studies, including a review of AUFI in South Asian countries [90]. A lack of an established diagnosis could be partly due to the fact that laboratory confirmations were not done in many studies of acute self-limiting viral infections. In addition, commercial serological rapid diagnostic tests used are semi- 
Table 4 Aetiology by region (Southeast Asia and South Asia)

\begin{tabular}{|c|c|c|c|}
\hline Organism & $\operatorname{SEA}(n ; \%)$ & South Asia $(n ; \%)$ & Total $(n ; \%)$ \\
\hline Viral aetiologies & $7828(33.0)$ & 7060 (12.4) & $14,888(18.5)$ \\
\hline Dengue & $2690(11.4)$ & $6821(12.0)$ & $9511(11.8)$ \\
\hline$J E^{* * *}$ & 309 (1.3) & $0(0.0)$ & $309(0.4)$ \\
\hline Influenza ${ }^{* *}$ & $2511(10.6)$ & $3(0.0)$ & $2514(3.1)$ \\
\hline $\mathrm{HINI}$ & $514(2.2)$ & $5(0.0)$ & $519(0.6)$ \\
\hline Chikungunya & $256(1.1)$ & $199(0.3)$ & $455(0.6)$ \\
\hline Hepatitis A & $62(0.3)$ & $11(0.0)$ & $73(0.1)$ \\
\hline Hepatitis B & $267(1.1)$ & $5(0.0)$ & $272(0.3)$ \\
\hline Hepatitis E & $1038(4.4)$ & $2(0.0)$ & $1040(1.3)$ \\
\hline Flavi virus & $65(0.3)$ & $0(0.0)$ & $65(0.1)$ \\
\hline Para influenza 1 & $10(0.0)$ & $0(0.0)$ & $10(0.0)$ \\
\hline Para influenza 3 & $28(0.1)$ & $0(0.0)$ & $28(0.0)$ \\
\hline Hanta virus & $71(0.3)$ & $2(0.0)$ & $73(0.1)$ \\
\hline HIV & $7(0.0)$ & $12(0.0)$ & $19(0.0)$ \\
\hline Bacterial aetiologies & $4873(20.6)$ & $5512(9.7)$ & $10,385(12.9)$ \\
\hline Leptospirosis & $2861(12.1)$ & $688(1.2)$ & $3549(4.4)$ \\
\hline Typhoid & 809 (3.4) & $2449(4.3)$ & $3258(4.0)$ \\
\hline Paratyphoid & $0(0.0)$ & $57(0.1)$ & $57(0.1)$ \\
\hline Rickettsial diseases & $1009(4.3)$ & 2234 (3.9) & $3243(4.0)$ \\
\hline Scrub typhus & 764 (3.2) & $2095(3.7)$ & 2859 (3.5) \\
\hline Murine typhus & $146(0.6)$ & $126(0.2)$ & $272(0.3)$ \\
\hline Spotted fever & $99(0.4)$ & $13(0.0)$ & $112(0.1)$ \\
\hline Q fever & $7(0.0)$ & $0(0.0)$ & $7(0.0)$ \\
\hline E coli & $49(0.2)$ & $9(0.0)$ & $58(0.1)$ \\
\hline Burkholderia pseudomallei & $23(0.1)$ & $0(0.0)$ & $23(0.0)$ \\
\hline Tuberculosis & $21(0.1)$ & $22(0.0)$ & $43(0.1)$ \\
\hline Klebsiella pneumoniae & $3(0.0)$ & $1(0.0)$ & $4(0.0)$ \\
\hline Haemophilus influenza & $9(0.0)$ & $0(0.0)$ & $9(0.0)$ \\
\hline Staph aureus & $49(0.2)$ & $0(0.0)$ & $49(0.1)$ \\
\hline Strep pneumoniae & $24(0.1)$ & $51(0.1)$ & $75(0.1)$ \\
\hline Strep Gr A & $2(0.0)$ & $0(0.0)$ & $2(0.0)$ \\
\hline Strep Gr C & $1(0.0)$ & $0(0.0)$ & $1(0.0)$ \\
\hline Neisseria meningitides & $6(0.0)$ & $1(0.0)$ & $7(0.0)$ \\
\hline Protozoa & $559(2.4)$ & $1722(3.0)$ & $2281(2.8)$ \\
\hline Malaria & $559(2.4)$ & $1722(3.0)$ & $2281(2.8)$ \\
\hline Fungal aetiologies & $3(0.0)$ & $0(0.0)$ & $3(0.0)$ \\
\hline Yeast non Cryptococci & $2(0.0)$ & $0(0.0)$ & $2(0.0)$ \\
\hline Cryptococcus neoformans & $1(0.0)$ & $0(0.0)$ & $1(0.0)$ \\
\hline Co infections & $815(3.4)$ & $196(0.3)$ & $1011(1.3)$ \\
\hline Co infection ${ }^{*}$ & $592(2.5)$ & $178(0.3)$ & $770(1.0)$ \\
\hline Co infection ${ }^{\dagger}$ & $217(0.9)$ & $18(0.0)$ & $235(0.3)$ \\
\hline
\end{tabular}


Table 4 Aetiology by region (Southeast Asia and South Asia) (Continued)

\begin{tabular}{|c|c|c|c|}
\hline Organism & $\operatorname{SEA}(n ; \%)$ & South Asia (n; \%) & Total $(n ; \%)$ \\
\hline Co infection $^{\ddagger}$ & $6(0.0)$ & $0(0.0)$ & $6(0.0)$ \\
\hline Unknown & $9621(40.6)$ & $42,389(74.5)$ & $52,010(64.5)$ \\
\hline Deaths & $114(30.2)$ & $264(69.8)$ & $378(100.0)$ \\
\hline
\end{tabular}

South Asian countries included: India, Bhutan, Bangladesh, Sri Lanka, and Nepal

Southeast Asian (SEA) countries included: Thailand, Indonesia, Malaysia, Laos, Philippines, Cambodia and Vietnam ${ }^{* * *}$ JE- Japanese B encephalitis;

${ }^{* *}$ influenza other than $\mathrm{H} 1 \mathrm{~N} 1$; ${ }^{*}$ co-infection with two organisms; ${ }^{\dagger}$ co-infection with three organisms; ${ }^{*}$ co-infection with more than three organisms

The bold face shows the cumulative number of the stratified groups

quantitative ELISAs that detect antibodies and are not conclusive of the present or past infection [91, 92]. For some pathogens, definitive diagnosis requires demonstration of a serial rise in antibody titres over a specific time period. Noncompliance of patients to report for repeat serological tests following improvement of the illness remains a major drawback in serology-based diagnostics [10, 93]. Moreover, ELISAs have poor specification and cross reactions are common [94]. Antigenbased or PCR-based diagnostics have been increasingly introduced to overcome these problems. However, their availability and affordability in resource-poor countries are limited, and the fact that they are not freely available in most government-run health institutions means that accessibility to such tests is limited to those in the private sector who can afford to pay from their own pocket [93].

This review has several limitations. Interpretation of data in this study should take into consideration the heterogeneity of the reviewed studies including study design, patient sampling and diagnostic testing. In addition, many of these studies were descriptive studies. Furthermore, there is no reliable way to judge the quality of heterogeneous descriptive studies included in this review. Some articles failed to report duration of fever and definition of AUFI varied widely between the studies. Aetiologies of AUFI of less than one-week duration would likely differ from those of a minimum of three weeks. Therefore, adherence to a common case definition between studies is important to make comparisons more reliable. Seasonal variation of diseases such as influenza, changes in disease patterns due to economic development, urbanization, environmental changes and changes in population densities during the last 15 years could have affected observed aetiologies and disease patterns. In addition, data from some countries including Bhutan and Timor-Leste were not available and results were also dominated by studies from India and Thailand. Since English is not the primary language in most of these countries, restricting the studies included in this review to studies published in English may have affected the findings.

Algorithms for the management of fevers at the community level as well as for inpatients have been developed by WHO [59]. A lack of knowledge of the geographical heterogeneity in AUFI aetiology prevents local adaptation of generic protocols, and thus precludes better targeting of drugs and implementation of early, effective management [95]. Therefore, it is necessary that data on pathogen presence collected incidentally in various studies and data collected by surveillance mechanisms be analysed systematically and mapped to provide information on the distribution and prevalence of infectious aetiologies of AFIs. Clinical algorithms could then be adapted, greatly improving targeting of treatment. Strengthening of notification systems (including sentinel systems) and sharing of data between clinical research communities will be important to construct more comprehensive information on geographically specific aetiologies of AUFI.

\section{Conclusion}

In this study the most common causes of AUFI were viral, followed by bacterial and protozoal (malaria) infections. Dengue was the commonest virus that caused AUFI while leptospirosis and typhoid were important bacterial infectious causes. The challenges of unidentified causes of AUFI can be partly overcome by roll-out of affordable serological tests. It is imperative that data on pathogen presence collected incidentally in various studies and data collected by surveillance systems be analysed systematically and mapped to provide information on the distribution and prevalence of infectious aetiologies of AFIs for improving treatment and prevention programmes.

\section{Additional file}

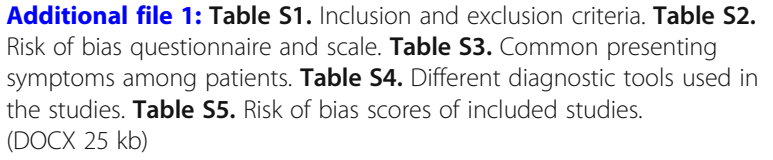

Additional file 1: Table S1. Inclusion and exclusion criteria. Table S2. Risk of bias questionnaire and scale. Table S3. Common presenting symptoms among patients. Table S4. Different diagnostic tools used in the studies. Table S5. Risk of bias scores of included studies. (DOCX $25 \mathrm{~kb}$ )

\section{Abbreviations}

AFI: acute febrile illness; AUFI: acute undifferentiated febrile illness; CFR: case fatality rate; DF: dengue fever; DHF: dengue haemorrhage fever; DSS: dengue shock syndrome; ED: emergency department; ELISA: enzyme-linked immunosorbent assay; HAV: Hepatitis A virus; HBV: Hepatitis B virus; HEV: Hepatitis E virus; IP : inpatients; JE: Japanese encephalitis; 
MAT: microscopic agglutination test; OPD: outpatient department; PCR: polymerase chain reaction; SA: South Asia; SEA: Southeast Asia; UAG: unspecified age group; WHO: World Health Organization

\section{Acknowledgements}

Not applicable.

\section{Authors' contributions}

ACAC, DJG, and KK conceived the review. KW and KK undertook the literature search, data extraction, and drafted the report. ACAC and DJG assisted in interpretation of results and was involved in the critical revision of report. SVN and CLL assisted in revision of this paper. All authors read and approved the final manuscript.

\section{Funding}

Not applicable.

\section{Availability of data and materials}

The data used for this analysis can be available upon request to the corresponding author (KW).

\section{Ethics approval and consent to participate}

Not applicable.

\section{Consent for publication}

Not applicable.

\section{Competing interests}

The authors declare that they have no competing interests.

\section{Author details}

'Department of Global Health, Research School of Population Health, Australian National University, Action, ACT, Canberra, Australia. ${ }^{2}$ Ministry of Health, Colombo, Sri Lanka. ${ }^{3}$ Kirby Institute, University of New South Wales, Sydney, NSW, Australia. ${ }^{4}$ Children's Health and Environment Program, Child Health Research Centre, The University of Queensland, QLD, South Brisbane, Australia. ${ }^{5}$ Faculty of Health Sciences, Curtin University, Perth, WA, Australia.

Received: 26 June 2018 Accepted: 12 June 2019

\section{Published online: 04 July 2019}

\section{References}

1. Chrispal A, Boorugu H, Gopinath KG, Chandy S, Prakash JA, Thomas EM, Abraham AM, Abraham OC, Thomas K. Acute undifferentiated febrile illness in adult hospitalized patients: the disease spectrum and diagnostic predictors - an experience from a tertiary care hospital in South India. Trop Dr. 2010;40(4):230-4.

2. Leelarasamee A, Chupaprawan C, Chenchittikul M, Udompanthurat S Etiologies of acute undifferentiated febrile illness in Thailand. Journal of the Medical Association of Thailand = Chotmaihet thangphaet. 2004; 87(5):464-72.

3. Acestor N, Cooksey R, Newton PN, Menard D, Guerin PJ, Nakagawa J, Christophel E, Gonzalez IJ, Bell D. Mapping the aetiology of non-malarial febrile illness in Southeast Asia through a systematic review--terra incognita impairing treatment policies. PLoS One. 2012;7(9):e44269.

4. Liu L, Johnson HL, Cousens S, Perin J, Scott S, Lawn JE, Rudan I, Campbell H, Cibulskis R, Li M, et al. Global, regional, and national causes of child mortality: an updated systematic analysis for 2010 with time trends since 2000. Lancet (London, England). 2012;379(9832):2151-61.

5. Bell M, Archibald LK, Nwanyanwu O, Dobbie H, Tokars J, Kazembe PN, Reller $L B$, Jarvis WR. Seasonal variation in the etiology of bloodstream infections in a febrile inpatient population in a developing country. International journal of infectious diseases : IJID : official publication of the International Society for Infectious Diseases. 2001;5(2):63-9.

6. Bharti AR, Nally JE, Ricaldi JN, Matthias MA, Diaz MM, Lovett MA, Levett PN, Gilman RH, Willig MR, Gotuzzo E, et al. Leptospirosis: a zoonotic disease of global importance. Lancet Infect Dis. 2003;3(12):757-71.

7. Pradutkanchana J, Pradutkanchana S, Kemapanmanus M, Wuthipum N, Silpapojakul K. The etiology of acute pyrexia of unknown origin in children after a flood. The Southeast Asian journal of tropical medicine and public health. 2003;34(1):175-8.
8. Bruce MG, Sanders EJ, Leake JA, Zaidel O, Bragg SL, Aye T, Shutt KA, Deseda CC, Rigau-Perez JG, Tappero JW, et al. Leptospirosis among patients presenting with dengue-like illness in Puerto Rico. Acta Trop. 2005:96(1):36-46.

9. Levett PN, Branch SL, Edwards CN. Detection of dengue infection in patients investigated for leptospirosis in Barbados. The American journal of tropical medicine and hygiene. 2000;62(1):112-4.

10. Dhingra B, Mishra D. Early diagnosis of febrile illness: the need of the hour. Indian Pediatr. 2011;48(11):845-9.

11. Capeding MR, Chua MN, Hadinegoro SR, Hussain II, Nallusamy R, Pitisuttithum P, Rusmil K, Thisyakorn U, Thomas SJ, Huu Tran N, et al. Dengue and other common causes of acute febrile illness in Asia: an active surveillance study in children. PLoS Negl Trop Dis. 2013;7(7):e2331.

12. Suttinont C, Losuwanaluk K, Niwatayakul K, Hoontrakul S, Intaranongpai W, Silpasakorn S, Suwancharoen D, Panlar P, Saisongkorh W, Rolain JM, et al. Causes of acute, undifferentiated, febrile illness in rural Thailand: results of a prospective observational study. Ann Trop Med Parasitol. 2006;100(4):363-70

13. Gibbons RV, Vaughn DW. Dengue: an escalating problem. BMJ (Clinical research ed). 2002;324(7353):1563-6.

14. Dash AP, Bhatia R, Sunyoto T, Mourya DT. Emerging and re-emerging arboviral diseases in Southeast Asia. Journal of vector borne diseases. 2013;50(2):77-84.

15. Vaughn DW, Green S, Kalayanarooj S, Innis BL, Nimmannitya S, Suntayakorn S, Endy TP, Raengsakulrach B, Rothman AL, Ennis FA, et al. Dengue viremia titer, antibody response pattern, and virus serotype correlate with disease severity. J Infect Dis. 2000;181(1):2-9.

16. Zaidi AK, Awasthi S, deSilva HJ. Burden of infectious diseases in South Asia. BMJ (Clinical research ed). 2004;328(7443):811-5.

17. Gubler DJ. The global emergence/resurgence of arboviral diseases as public health problems. Arch Med Res. 2002;33(4):330-42

18. Coker RJ, Hunter BM, Rudge JW, Liverani M, Hanvoravongchai P. Emerging infectious diseases in Southeast Asia: regional challenges to control. Lancet (London, England). 2011;377(9765):599-609.

19. Hoy D, Brooks P, Woolf A, Blyth F, March L, Bain C, Baker P, Smith E, Buchbinder R. Assessing risk of bias in prevalence studies: modification of an existing tool and evidence of interrater agreement. J Clin Epidemiol. 2012;65(9):934-9.

20. Abhilash KP, Jeevan JA, Mitra S, Paul N, Murugan TP, Rangaraj A, David S, Hansdak SG, Prakash JA, Abraham AM, et al. Acute undifferentiated febrile illness in patients presenting to a tertiary Care Hospital in South India: clinical Spectrum and outcome. J Global Infect Dis. 2016;8(4):147-54.

21. Gopalakrishnan S, Arumugam B, Kandasamy S, Rajendran S, Krishnan B. Acute undifferentiated febrile illness among adults - a hospital based observational study. J Evol Med Dent Sci. 2013;2(14):2305-19.

22. Joshi R, Colford JM Jr, Reingold AL, Kalantri S. Nonmalarial acute undifferentiated fever in a rural hospital in Central India: diagnostic uncertainty and overtreatment with antimalarial agents. The American journal of tropical medicine and hygiene. 2008;78(3):393-9.

23. Kammili N, Swathi A, Devara SM, Anuradha pR. Prevalence of scrub typhus among acute undifferentiated febrile illness cases provisionally diagnosed as dengue fever. J Evol Med Dent Sci. 2013;2(16):2662-4.

24. Kasper MR, Blair PJ, Touch S, Sokhal B, Yasuda CY, Williams M, Richards AL, Burgess TH, Wierzba TF, Putnam SD. Infectious etiologies of acute febrile illness among patients seeking health care in south-Central Cambodia. The American journal of tropical medicine and hygiene. 2012;86(2):246-53.

25. Laoprasopwattana K, Kaewjungwad L, Jarumanokul R, Geater A. Differential diagnosis of chikungunya, dengue viral infection and other acute febrile illnesses in children. Pediatr Infect Dis J. 2012;31(5):459-63.

26. Mayxay M, Castonguay-Vanier J, Chansamouth V, Dubot-Pérès A, Paris DH, Phetsouvanh R, Tangkhabuanbutra J, Douangdala P, Inthalath S, Souvannasing $P$, et al. Causes of non-malarial fever in Laos: a prospective study. Lancet Glob Health. 2013;1(3):e46-54.

27. Oishr K, A Maputa C, Carlos CC, Cinco-Abanes MT, Saoto M, Inoue S, Morita K, Natividad FF: Dengue and other Febric illnesses among Children in the Philippines. 2006.

28. Phuong HL, de Vries PJ, Nga TT, Giao PT, Hung le Q, Binh TQ, Nam NV, Nagelkerke N, Kager PA. Dengue as a cause of acute undifferentiated fever in Vietnam. BMC Infect Dis. 2006;6:123.

29. Ray P, Ratagiri VH, Kabra SK, Lodha R, Sharma S, Sharma BS, Kalaivani M, Wig N. Chikungunya infection in India: results of a prospective hospital based multi-centric study. PLoS One. 2012;7(2):e30025. 
30. Reller ME, Bodinayake C, Nagahawatte A, Devasiri V, Kodikara-Arachichi W, Strouse JJ, Broadwater A, Ostbye T, de Silva A, Woods CW. Unsuspected dengue and acute febrile illness in rural and semi-urban southern Sri Lanka. Emerg Infect Dis. 2012;18(2):256-63.

31. Reller ME, Bodinayake C, Nagahawatte A, Devasiri V, Kodikara-Arachichi W, Strouse JJ, Flom JE, Dumler JS, Woods CW. Leptospirosis as frequent cause of acute febrile illness in southern Sri Lanka. Emerg Infect Dis. 2011;17(9): 1678-84.

32. Raina S, Raina RK, Agarwala N, Raina SK, Sharma R. Coinfections as an aetiology of acute undifferentiated febrile illness among adult patients in the sub-Himalayan region of North India. Journal of vector borne diseases. 2018;55(2):130-6.

33. Shelke YP, Deotale VS, Maraskolhe DL. Spectrum of infections in acute febrile illness in Central India. Indian J Med Microbiol. 2017;35(4):480-4.

34. Andrews MA, Ittyachen AM. Aetiology of acute febrile illness: a multicentre study from the province of Kerala in southern India. Trop Dr. 2018;48(4): 322-5.

35. Bodinayake CK, Tillekeratne LG, Nagahawatte A, Devasiri V, Kodikara Arachchi W, Strouse JJ, Sessions OM, Kurukulasooriya R, Uehara A, Howe S, et al. Evaluation of the WHO 2009 classification for diagnosis of acute dengue in a large cohort of adults and children in Sri Lanka during a dengue-1 epidemic. PLoS Negl Trop Dis. 2018;12(2):e0006258.

36. Murdoch DR, Woods CW, Zimmerman MD, Dull PM, Belbase RH, Keenan AJ, Scott RM, Basnyat B, Archibald LK, Reller LB. The etiology of febrile illness in adults presenting to Patan hospital in Kathmandu, Nepal. The American journal of tropical medicine and hygiene. 2004;70(6):670-5.

37. Kashinkunti MD, Gundikeri SK, Dhananjaya M. Acute undifferentiated febrile illness- clinical spectrum and outcome from a tertiary care teaching hospital of North Karnataka. Int J Biol Med Res. 2013;4(2):3399-402.

38. Kingston HW, Hossain M, Leopold S, Anantatat T, Tanganuchitcharnchai A, Sinha I, Plewes K, Maude RJ, Chowdhury MAH, Paul S, et al. Rickettsial illnesses as important causes of febrile illness in Chittagong, Bangladesh. Emerg Infect Dis. 2018;24(4).

39. Kumar R, Tripathi P, Tripathi S, Kanodia A, Pant S, Venkatesh V. Prevalence and clinical differentiation of dengue fever in children in northern India. Infection. 2008:36(5):444-9.

40. Wangrangsimakul T, Althaus T, Mukaka M, Kantipong P, Wuthiekanun V, Chierakul W, Blacksell SD, Day NP, Laongnualpanich A, Paris DH. Causes of acute undifferentiated fever and the utility of biomarkers in Chiangrai, northern Thailand. PLoS Negl Trop Dis. 2018;12(5):e0006477.

41. Zaki SA, Shanbag P. Clinical manifestations of dengue and leptospirosis in children in Mumbai: an observational study. Infection. 2010:38(4):285-91.

42. Chheng K, Carter MJ, Emary K, Chanpheaktra N, Moore CE, Stoesser N, Putchhat $\mathrm{H}$, Sona $\mathrm{S}$, Reaksmey $\mathrm{S}$, Kitsutani $\mathrm{P}$, et al. A prospective study of the causes of febrile illness requiring hospitalization in children in Cambodia. PLoS One. 2013;8(4):e60634.

43. Punjabi NH, Taylor WR, Murphy GS, Purwaningsih S, Picarima H, Sisson J, Olson JG, Baso S, Wangsasaputra F, Lesmana M, et al. Etiology of acute, non-malaria, febrile illnesses in Jayapura, northeastern Papua, Indonesia. The American journal of tropical medicine and hygiene. 2012;86(1):46-51.

44. Ahmad S, Dhar M, Mittal G, Bhat NK, Shirazi N, Kalra V, Sati HC, Gupta V. A comparative hospital-based observational study of monoand co-infections of malaria, dengue virus and scrub typhus causing acute undifferentiated fever. European journal of clinical microbiology \& infectious diseases : official publication of the. European Society of Clinical Microbiology. 2016;35(4):705-11.

45. Andrews M, Elizabeth A, Kuttichira P. Clinical profile of acute undifferentiated febrile illness in patients admitted to a teaching hospital in Kerala. Health Sciences. 2014;(3):1

46. Arora BS, Matlani M, Saigal K, Biswal I, Rajan S, Padmanandan A, Singh S: major aetiologies of acute undifferentiated fever in 2013 and 2014: an experience in retrospect. 2017 2017, 4(2):5.

47. Chikkaveeraiah SK, Bhograj A, Reddy R, Kumar A. Evaluating the etiology and disease specific clinical profiles of acute undifferentiated febrile illness. International Journal of Scientific Study. 2016(12):3

48. Das D, Das B, Roy AD, Singh T. Common infectious etiologies of acute febrile illness in a remote geographical location: could scrub typhus be the Most common cause? British Journal of Medicine \& Medical Research. 2015; 10(10):1-10

49. Ellis RD, Fukuda MM, McDaniel P, Welch K, Nisalak A, Murray CK, Gray MR, Uthaimongkol N, Buathong N, Sriwichai S, et al. Causes of fever in adults on the Thai-Myanmar border. The American journal of tropical medicine and hygiene. 2006;74(1):108-13.

50. McGready R, Ashley EA, Wuthiekanun V, Tan SO, Pimanpanarak M, ViladpaiNquen SJ, Jesadapanpong W, Blacksell SD, Peacock SJ, Paris DH, et al. Arthropod borne disease: the leading cause of fever in pregnancy on the Thai-Burmese border. PLoS Negl Trop Dis. 2010;4(11):e888.

51. Mittal G, Ahmad S, Agarwal RK, Dhar M, Mittal M, Sharma S. Aetiologies of acute undifferentiated febrile illness in adult patients - an experience from a tertiary care hospital in northern India. Journal of clinical and diagnostic research : JCDR. 2015;9(12):Dc22-4.

52. Rafizah AAN, Aziah BD, Azwany YN, Imran MK, Rusli AM, Nazri M, Nabilah I, Zahirunddin WM, Zaliha I. Leptospirosis in northeastern Malaysia: misdiagnosed or coinfection? International Journal of Collaborative Research on Internal Medicine \& Public Health. 2012;4(7):1420-7.

53. Rani RV, Sundararajan T, Rajesh S, Jeyamurugan T. A study on common etiologies of acute febrile illness detectable by microbiological tests in a tertiary care hospital. Int J Curr Microbiol App Sci. 2016;5(7):670-4.

54. Sabchareon A, Sirivichayakul C, Limkittikul K, Chanthavanich P, Suvannadabba S, Jiwariyavej V, Dulyachai W, Pengsaa K, Margolis HS, Letson GW. Dengue infection in children in Ratchaburi, Thailand: a cohort study. I. Epidemiology of symptomatic acute dengue infection in children, 20062009. PLoS Negl Trop Dis. 2012;6(7):e1732.

55. Salagre KD, Sahay RN, Pazare AR, Dubey A, Marathe KK. A study of clinical profile of patients presenting with complications of acute febrile illnesses during monsoon. J Assoc Physicians India. 2017;65(9):37-42.

56. Thompson CN, Blacksell SD, Paris DH, Arjyal A, Karkey A, Dongol S, Giri A, Dolecek C, Day N, Baker S, et al. Undifferentiated febrile illness in Kathmandu, Nepal. The American journal of tropical medicine and hygiene. 2015;92(4):875-8.

57. Gautam R, Parajuli K, Sherchand JB. Epidemiology, risk factors and seasonal variation of scrub typhus fever in Central Nepal. Tropical medicine and infectious disease. 2019;4(1).

58. Prasad N, Murdoch DR, Reyburn H, Crump JA. Etiology of severe febrile illness in low- and middle-income countries: a systematic review. PLoS One. 2015;10(6):e0127962.

59. WHO: WHO informal consultation on fever management in peripheral health care settings: a global review of evidence and practice. In. Geneva, Switzerland; 2013.

60. Moreira J, Bressan CS, Brasil P, Siqueira AM. Epidemiology of acute febrile illness in Latin America. Clinical microbiology and infection : the official publication of the European Society of Clinical. Microbiology and Infectious Diseases. 2018:24(8):827-35.

61. Laras K, Cao BV, Bounlu K, Nguyen TK, Olson JG, Thongchanh S, Tran NV, Hoang KL, Punjabi N, Ha BK, et al. The importance of leptospirosis in Southeast Asia. The American journal of tropical medicine and hygiene. 2002;67(3):278-86

62. Sehgal SC, Sugunan AP, Vijayachari P. Leptospirosis disease burden estimation and surveillance networking in India. The Southeast Asian journal of tropical medicine and public health. 2003;34(2):170-7.

63. Tangkanakul W, Smits HL, Jatanasen S, Ashford DA. Leptospirosis: an emerging health problem in Thailand. The Southeast Asian journal of tropical medicine and public health. 2005;36(2):281-8.

64. LaRocque RC, Breiman RF, Ari MD, Morey RE, Janan FA, Hayes JM, Hossain MA, Brooks WA, Levett PN. Leptospirosis during dengue outbreak, Bangladesh. Emerg Infect Dis. 2005;11(5):766-9.

65. Costa F, Hagan JE, Calcagno J, Kane M, Torgerson P, Martinez-Silveira MS, Stein C, Abela-Ridder B, Ko Al. Global morbidity and mortality of leptospirosis: a systematic review. PLoS Negl Trop Dis. 2015;9(9):e0003898.

66. Tangkanakul W, Tharmaphornpil P, Plikaytis BD, Bragg S, Poonsuksombat D, Choomkasien P, Kingnate D, Ashford DA. Risk factors associated with leptospirosis in northeastern Thailand, 1998. The American journal of tropical medicine and hygiene. 2000;63(3-4):204-8.

67. Kamath R, Swain S, Pattanshetty S, Nair NS. Studying risk factors associated with human leptospirosis. J Global Infect Dis. 2014;6(1):3-9.

68. Torgerson PR, Hagan JE, Costa F, Calcagno J, Kane M, Martinez-Silveira MS, Goris MG, Stein C, Ko Al, Abela-Ridder B. Global burden of leptospirosis: estimated in terms of disability adjusted life years. PLoS Negl Trop Dis. 2015; 9(10):e0004122

69. Victoriano AF, Smythe LD, Gloriani-Barzaga N, Cavinta LL, Kasai T, Limpakarnjanarat K, Ong BL, Gongal G, Hall J, Coulombe CA, et al. Leptospirosis in the Asia Pacific region. BMC Infect Dis. 2009;9:147. 
70. Libraty DH, Myint KS, Murray CK, Gibbons RV, Mammen MP, Endy TP, Li W, Vaughn DW, Nisalak A, Kalayanarooj S, et al. A comparative study of leptospirosis and dengue in Thai children. PLoS Negl Trop Dis. 2007; 1(3):e111.

71. Toyokawa T, Ohnishi M, Koizumi N. Diagnosis of acute leptospirosis. Expert Rev Anti-Infect Ther. 2011;9(1):111-21.

72. Levett PN. Leptospirosis. Clin Microbiol Rev. 2001;14(2):296-326.

73. Khan E, Kisat M, Khan N, Nasir A, Ayub S, Hasan R. Demographic and clinical features of dengue fever in Pakistan from 2003-2007: a retrospective crosssectional study. PLoS One. 2010;5(9):e12505.

74. Hoti SL, R. S, Rajendran G, Das LK, Ravi R, Das PK: Dengue and Dengue haemorrhagic fever outbreak in Pondicherry, South India, during 20032004, Emergence of DENV-3. Dengue Bulletin 2006, 30:42-50.

75. Teng AK, Singh S. Epidemiology and new initiatives in the prevention and control of dengue in Malaysia. Dengue Bulletin. 2001;25:7-14.

76. Lee LK, Earnest A, Carrasco LR, Thein TL, Gan VC, Lee VJ, Lye DC, Leo YS. Safety and cost savings of reducing adult dengue hospitalization in a tertiary care hospital in Singapore. Trans R Soc Trop Med Hyg. 2013; 107(1):37-42.

77. Sturm-Ramirez KM, Hulse-Post DJ, Govorkova EA, Humberd J, Seiler P, Puthavathana P, Buranathai C, Nguyen TD, Chaisingh A, Long HT, et al. Are ducks contributing to the endemicity of highly pathogenic $\mathrm{H} 5 \mathrm{~N} 1$ influenza virus in Asia? J Virol. 2005:79(17):11269-79.

78. Sims LD. Lessons learned from Asian H5N1 outbreak control. Avian Dis. 2007:51(1 Suppl):174-81.

79. Forrest HL, Webster RG. Perspectives on influenza evolution and the role of research. Anim Health Res Rev. 2010;11(1):3-18.

80. Influenza (Seasonal) [http://www.who.int/mediacentre/factsheets/fs211/en/].

81. Ochiai RL, Acosta CJ, Danovaro-Holliday MC, Baiqing D, Bhattacharya SK, Agtini MD, Bhutta ZA, Canh DG, Ali M, Shin S, et al. A study of typhoid fever in five Asian countries: disease burden and implications for controls. Bull World Health Organ. 2008;86(4):260-8.

82. Chaudhry D, Goyal S. Scrub typhus-resurgence of a forgotten killer. Indian journal of anaesthesia. 2013;57(2):135-6.

83. Fan MY, Walker DH, Yu SR, Liu QH. Epidemiology and ecology of rickettsial diseases in the People's Republic of China. Rev Infect Dis. 1987;9(4):823-40.

84. Parola P, Miller RS, McDaniel P, Telford SR 3rd, Rolain JM, Wongsrichanalai C, Raoult D. Emerging rickettsioses of the Thai-Myanmar border. Emerg Infect Dis. 2003;9(5):592-5.

85. Kularatne SA, Edirisingha JS, Gawarammana IB, Urakami H, Chenchittikul M, Kaiho I. Emerging rickettsial infections in Sri Lanka: the pattern in the hilly Central Province. Tropical medicine \& international health : TM \& IH. 2003; 8(9):803-11.

86. WHO: E2020: update on the e-2020 initiative of 21 malaria-eliminating countries. 2018.

87. WHO: world malaria report 2017. WHO Library Cataloguing-in-Publication Data 2017.

88. Behera B, Chaudhry R, Pandey A, Mohan A, Dar L, Premlatha MM, Gupta E, Broor S, Aggarwal P. Co-infections due to leptospira, dengue and hepatitis E: a diagnostic challenge. Journal of infection in developing countries. 2009; 4(1):48-50.

89. Chaudhry R, Pandey A, Das A, Broor S. Infection potpourri: are we watching? Indian journal of pathology \& microbiology. 2009;52(1):125.

90. Peacock SJ, Newton PN. Public health impact of establishing the cause of bacterial infections in rural Asia. Trans R Soc Trop Med Hyg. 2008;102(1):5-6.

91. Blacksell SD, Bryant NJ, Paris DH, Doust JA, Sakoda Y, Day NP. Scrub typhus serologic testing with the indirect immunofluorescence method as a diagnostic gold standard: a lack of consensus leads to a lot of confusion. Clinical infectious diseases : an official publication of the Infectious Diseases Society of America. 2007:44(3):391-401.

92. Wagenaar JF, Falke TH, Nam NV, Binh TQ, Smits HL, Cobelens FG, de Vries PJ. Rapid serological assays for leptospirosis are of limited value in southern Vietnam. Ann Trop Med Parasitol. 2004:98(8):843-50.

93. Premaratna R. Dealing with acute febrile illness in the resource poor tropics. Tropical Medicine \& Surgery. 2013(1):1

94. Lau CL, DePasquale JM: Leptospirosis, American Samoa. Emerg Infect Dis 2012, 18(12):2079-2081.

95. FIND: acute febrile syndrome Straegy. In.; 2012

\section{Publisher's Note}

Springer Nature remains neutral with regard to jurisdictional claims in published maps and institutional affiliations.
Ready to submit your research? Choose BMC and benefit from:

- fast, convenient online submission

- thorough peer review by experienced researchers in your field

- rapid publication on acceptance

- support for research data, including large and complex data types

- gold Open Access which fosters wider collaboration and increased citations

- maximum visibility for your research: over $100 \mathrm{M}$ website views per year

At BMC, research is always in progress.

Learn more biomedcentral.com/submissions 